\title{
Purification and Identification of Novel Antioxidant Peptides from Enzymatically Hydrolysed Samia ricini Pupae
}

\author{
Nattakarn Wongsrangsap and Suttida Chukiatsiri *
}

Citation: Wongsrangsap, N.; Chukiatsiri, S. Purification and Identification of Novel Antioxidant Peptides from Enzymatically Hydrolysed Samia ricini Pupae. Molecules 2021, 26, 2588.

https://doi.org/10.3390/molecules 26092588

Academic Editor: Goran Mitulović

Received: 16 March 2021

Accepted: 27 April 2021

Published: 29 April 2021

Publisher's Note: MDPI stays neutral with regard to jurisdictional claims in published maps and institutional affiliations.

\author{
Department of Biochemistry, Faculty of Science, Kasetsart University, 50 Ngam Wong Wan Road, Ladyao, \\ Chatuchak, Bangkok 10900, Thailand; nattakarn.won@ku.th \\ * Correspondence: to: suttida.e@ku.th
}

\begin{abstract}
The emergence of excessive free radicals leads to the destruction of various systems within the body. These free radicals also affect nutritional values, color, taste, and emit an odor akin to rancid food. Most food industries use synthetic antioxidants, such as BHT (butylated hydroxytoluene) or BHA (butylated hydroxy anisole). However, high doses of these can be harmful to our health. Therefore, an antioxidant compounds, such as bioactive peptides from edible animals or plants, have emerged to be a very promising alternative as they reduce potential side effects. This study focused on the purification and identification of antioxidant peptides from protein hydrolysates of wild silkworm pupae (Samia ricini). Antioxidant peptides were purified from the hydrolysate by ultrafiltration and RP-HPLC. The results showed that protein hydrolysate from S. ricini pupae by trypsin with a molecular weight lower than $3 \mathrm{kDa}$ and highly hydrophobic property, exhibited strong DPPH radical scavenging activity and chelating activity. Further identification of peptides from the fraction with the highest antioxidant activity was carried out using LC-MS/MS. Three novel peptides, i.e., Met-Ley-Ile-Ile-Ile-Met-Arg, Leu-Asn-Lys-Asp-Leu-Met-Arg, and Glu-Asn-Ile-Ile-Leu-Phe-Arg, were identified. The results of this study indicated that the protein hydrolysate from $S$. ricini pupae possessed potent biological activity, and the novel antioxidant peptides could be utilized to develop health-related antioxidants in food industry.
\end{abstract}

Keywords: Samia ricini pupae; enzymatic protein hydrolysates; antioxidant peptides; antioxidant activity

\section{Introduction}

Free radicals are derived either from normal essential metabolic processes in the human body or from external sources. Many radicals are highly reactive. They play major roles in biochemical pathways and food degradation [1-3]. These also affect color, taste, odor, and nutritional values of food [4,5]. BHT (butylated hydroxytoluene) and BHA (butylated hydroxy anisole) are two widely used synthetic antioxidants in foods. However, they display some toxic and hazardous effects on human health [6,7]. These effects include attention-deficit hyperactivity disorder (ADHD), allergy, and dermatitis, or contribute to cancer $[8,9]$. Thus, more studies have focused on natural antioxidants.

Samia ricini is a non-mulberry, multivoltine, domestic sericigenous insect, largely reared by the farmers of northeastern states of India, where it is grown primarily for silk production and food. S. ricini pupae are by-products of silk industry. Previous showed that S. ricini pupae contain significantly high levels of phenolic [10]. According to the protein digestibility corrected amino acid score (PDCAAS), S. ricini pupae achieved a score of $87 \%$. They also have $54 \%$ protein contents of dry weight, with abundant essential amino acids, such as methionine, leucine, phenylalanine, lysine, valine, and isoleucine [11]. S. ricini pupae contain essential fatty acids, such as $\alpha$-linolenic acid, arachidic, lignoceric, and important vitamins and minerals, such as phosphorus, iron, calcium, and magnesium [12]. In addition, protein extracts from $S$. ricini pupae have been identified to exert anticancer effects by downregulating the expression of IL-6, IL-1 $\beta$ and TNF- $\alpha$ through biomolecular 
changes in human breast cancer cells [13]. However, antioxidant peptides from S. ricini pupae have not been identified.

In this study, three novel antioxidant peptides from enzymatically hydrolyzed S. ricini pupae were purified and identified. Protein extracts from S. ricini pupae were hydrolyzed by trypsin and pepsin. Antioxidant activities were evaluated with DPPH and iron (FeII) chelation. The antioxidant peptides were purified by reverse-phase high performance liquid chromatography (RP-HPLC), and the amino acids sequences were identified by liquid chromatography with tandem mass spectrometry (LC-MS/MS).

\section{Materials and Methods}

\subsection{Materials and Reagents}

Samia ricini pupae were provided by the Kasetsart University Smart Silk Centre, Kasetsart University, Thailand. Chemicals and reagents were purchased from the following organizations: Sodium chloride $(\mathrm{NaCl})$, ethylenediaminetetraacetic acid (EDTA), and sodium dodecyl sulfate (SDS)—from Bio Basic Inc. (Markham, ON, Canada), TritonX-100from Scharlau Chemie S.A. Co. (Barcelona, Spain), phenylmethylsulfonyl fluoride (PMSF) and hydrochloric acid $(\mathrm{HCl}$ - from Sigma-Aldrich, Inc. (Munich, Germany), Pepsin from ELITechGroup Inc. (Washington, WA, USA), 1,10-phenanthroline monohydrate-from Univar Solutions Inc. (Denver, CO, USA), acetonitrile-from VWR International LLC. (Fontenay-sous-Bois, France), trifluoroacetic acid (TFA)—from Thermo Fisher Scientific Inc. (Leics., UK). All other reagents used were of analytical grade and were purchased from Sigma-Aldrich Inc. (St. Louis, MO, USA), or were available commercially.

\subsection{Preparation of Protein Extraction S. ricini}

S. ricini was weighed to blend with a buffer solution consisting of $50 \mathrm{mM}$ Tris- $\mathrm{HCl}$ (pH 7.4), $150 \mathrm{mM} \mathrm{NaCl}, 1 \mathrm{mM}$ EDTA, $1 \%$ TritonX100, 0.1\% SDS and $4 \mathrm{mM}$ PMSF, then sampled by centrifuge at $14,000 \times g$ at $4{ }^{\circ} \mathrm{C}$ for $10 \mathrm{~min}$. The supernatant obtained was dialyzed overnight $(\mathrm{O} / \mathrm{N})$ with distilled water which was changed at least three times, every $4 \mathrm{~h}$ crude protein concentrations were measured using a nanodrop microvolume UV-VIS spectrophotometers (Thermo Fisher Scientific Inc., Waltham, MA, USA).

\subsection{Preparation of Hydrolysates and Fractionation with Ultrafiltration Membranes}

The sample was dissolved in distilled water at a concentration of $25 \mathrm{mg} / \mathrm{mL}$ and hydrolyzed for $12 \mathrm{~h}$ using trypsin at $\mathrm{pH} 8.0$ at $37^{\circ} \mathrm{C}$ and papain at $\mathrm{pH} 6.0$ at $50{ }^{\circ} \mathrm{C}$ for $6 \mathrm{~h}$ using pepsin at $\mathrm{pH} 2.2$ at $37^{\circ} \mathrm{C}(1 \mathrm{mg}$ of enzyme $/ 25 \mathrm{mg}$ protein), followed by enzyme activity termination by heating for $10 \mathrm{~min}$ in boiling water. The samples were then centrifuged at $9000 \times \mathrm{g}$ at $4{ }^{\circ} \mathrm{C}$ for $15 \mathrm{~min}$, and the supernatants stored at $-20^{\circ} \mathrm{C}$ for further analysis.

\subsection{Purification of the Antioxidant Peptides from S. ricini Pupae}

\subsubsection{Ultrafiltration}

The hydrolysate sample was fractionated using ultrafiltration membrane (Millipore, Darmstadt, Germany) according to the instructions in the manual (Amicon ${ }^{\circledR}$ Ultra filter) with MW cut-offs of 3,10, and $30 \mathrm{kDa}$. The permeates or retentates were collected as $>30 \mathrm{kDa},<30 \mathrm{kDa}, 10-30 \mathrm{kDa},<10 \mathrm{kDa}, 3-10 \mathrm{kDa}$, and $<3 \mathrm{kDa}$, respectively. All permeates were stored at $-20^{\circ} \mathrm{C}$ for further analysis.

\subsubsection{RT-HPLC}

S. ricini, hydrolyzed with trypsin, was purified by RT-HPLC (Perkin Elmer 200 Series, PerkinElmer Inc., Waltham, MA, USA) according to the method of Xing, L.-j., et al. [14] with a slight modification. Purification was carried out using a Thermo C18 column (diameter $4.5 \mathrm{~mm}$, length $250 \mathrm{~mm}$, particle size $5 \mu \mathrm{m}$, Thermo Fisher Scientific Inc., Waltham, MA, USA). For separation part, solvent composition of the mobile phase at the two channels was $0.1 \%(v / v)$ formic acid and $2 \%(v / v)$ acetonitrile for channel A and $0.1 \%(v / v)$ formic 
acid and $100 \%(v / v)$ acetonitrile for channel B. The peptides were separated by a gradient elution to $30 \% \mathrm{~B}$ in $2 \mathrm{~min}$, to $80 \% \mathrm{~B}$ in $18 \mathrm{~min}$, to $100 \% \mathrm{~B}$ in $7 \mathrm{~min}$.

The flow rate was set at $0.3 \mathrm{~mL} / \mathrm{min}$, measured at wavelengths of $220 \mathrm{~nm}$, and collected fractions were stored at $-20^{\circ} \mathrm{C}$ for further analysis.

\subsubsection{LC-MS/MS}

S. ricini fractions were determined with a 6420 triple quadrupole LC/MS (Agilent Technologies, Inc., Santa Clara, CA, USA), coupled with an electrospray ionization source (ESI), recording the mass spectral range of $50-1506 \mathrm{~m} / \mathrm{z}$. The linear gradients of solution A and solution B were based on the RP-HPLC method.

\subsection{Determination of Antioxidant Activity}

\subsubsection{DPPH Radical Scavenging Activity}

DPPH radical scavenging activity was measured according to the method of Blois, M. S. J. N. [15]. The sample was diluted with deionized water (BHA and BHT were used as positive controls) and added to $50 \mu \mathrm{L}$ of $0.125 \mathrm{mM}$ 2,2-diphenyl-1-picrythyhydrazyl radical (DPPH) in 70\% ethanol. The mixture was left at room temperature for $30 \mathrm{~min}$ in the dark, and the absorbance was measured at $517 \mathrm{~nm}$ (NanoDrop ONE, Thermo Fisher Scientific Inc., USA). The activity was expressed as a percentage DPPH scavenging relative to control, using the following equation:

$$
\% \text { Radical scavenging activity }=\left(1-\left(A_{\text {sample }} / A_{\text {control }}\right)\right) \times 100
$$

where $A_{\text {sample }}$ is the absorbance of sample and $A_{\text {control }}$ is the absorbance of the control. The $\mathrm{IC}_{50}$ value is defined as an inhibitory concentration of sample that is required to scavenge $50 \%$ of radical activity.

\subsubsection{Iron Chelating Activity}

The iron chelating activity was measured according to the method of Chaudhary, S., et al. [16]. Sample and control were prepared, and were added to $30 \mu \mathrm{L}$ of methanol and $20 \mu \mathrm{L}$ of 1 , 10-phenanthroline-iron (III). 1, 10-henanthroline-iron (III) was prepared by $0.198 \mathrm{~g}$ of 1, 10phenanthroline monohydrate, $2 \mathrm{~mL}$ of $1 \mathrm{M}$ hydrochloric acid, and $0.16 \mathrm{~g}$ mixed to incubated at $50{ }^{\circ} \mathrm{C}$ for $30 \mathrm{~min}$ in the dark, and the absorbance was measured at $510 \mathrm{~nm}$ (NanoDrop ONE, Thermo Fisher Scientific Inc., USA). The activity was expressed as a percentage of iron chelating activity to control, using the following equation:

$$
\% \text { Chelating activity }=\left(1-\left(A_{\text {sample }} / A_{\text {control }}\right)\right) \times 100
$$

where $A_{\text {sample }}$ is the absorbance of sample and $A_{\text {control }}$ is the absorbance of the control. The $\mathrm{IC}_{50}$ value is defined as an inhibitory concentration of sample that is required to chelate $50 \%$ of activity.

\subsection{Statistical Analysis}

The experiments were performed in triplicate $(n=3)$ and the results expressed as the mean \pm standard deviation (SD) by GraphPad Prism 8.0.1 (244) (GraphPad Software, San Diego, CA, USA). One-way analysis of ANOVA (and nonparametric or mixed) indicated significant differences.

\section{Results}

\subsection{Preparation of Protein Hydrolysates of S. ricini Pupae}

In this research, different proteolytic enzymes were used, including trypsin and pepsin. DPPH is a commonly-used method of assessing antioxidant abilities as it is a simple, easy, inexpensive, and precise method, and the best method in in vitro [17-21]. Iron chelating is a test of iron-binding capacity, as an excess of iron in the body can 
also lead to an increase of free radicals [22,23]. The following Tables 1 and 2 show the antioxidant activity of protein hydrolysates with trypsin and pepsin, comparable with BHA (positive control). The DPPH scavenging activity presented as $\mathrm{IC}_{50}$ values is shown in Table 1. Protein hydrolysate with trypsin $\left(\mathrm{IC}_{50}=1406.6 \pm 86.9 \mu \mathrm{g} / \mathrm{mL}\right)$, and with pepsin $\left(\mathrm{IC}_{50}=1495.6 \pm 101.7 \mu \mathrm{g} / \mathrm{mL}\right)$ showed no significant difference when compared with BHA $\left(\mathrm{IC}_{50}=1304.5 \pm 75.4 \mu \mathrm{g} / \mathrm{mL}\right)$. However, protein hydrolysate with pepsin exhibited the strongest chelating activity $\left(\mathrm{IC}_{50}=189.3 \pm 57.1 \mu \mathrm{g} / \mathrm{mL}\right)$ compared to protein hydrolysate with trypsin $\left(\mathrm{IC}_{50}=286.5 \pm 48.7 \mu \mathrm{g} / \mathrm{mL}\right)$, or BHA $\left(\mathrm{IC}_{50}=297.8 \pm 29.6 \mu \mathrm{g} / \mathrm{mL}\right)($ Table 2$)$.

Table 1. DPPH radical scavenging activity of protein hydrolysates from S. ricini pupae.

\begin{tabular}{cc}
\hline Samples & $\begin{array}{c}\text { DPPH Radical Scavenging Activity } \\
\mathbf{( I C}_{\mathbf{5 0} \boldsymbol{\mu} / \mathbf{m L})}\end{array}$ \\
\hline Crude protein & $1808.1 \pm 98.0^{\mathrm{b}}$ \\
Protein hydrolysate with trypsin & $1406.6 \pm 86.9^{\mathrm{a}}$ \\
Protein hydrolysate with pepsin & $1495.6 \pm 101.7^{\mathrm{a}}$ \\
BHA & $1304.5 \pm 75.4^{\mathrm{a}}$ \\
\hline
\end{tabular}

Values are mean of three replicate determinations $(n=3) \pm$ standard deviation. Mean values followed by different superscripts $(\mathrm{a}, \mathrm{b})$ in a column are significantly different $(p<0.05$; ANOVA, followed by Tukey's multiple comparison test).

Table 2. Iron chelating activity of protein hydrolysates from S. ricini pupae.

\begin{tabular}{cc}
\hline Samples & $\begin{array}{c}\text { Iron Chelating Activity } \\
\left(\mathbf{I C}_{\mathbf{5 0}} \boldsymbol{\mu g} / \mathbf{m L} \mathbf{)}\right.\end{array}$ \\
\hline Crude protein & $300.7 \pm 38.2^{\mathrm{a}}$ \\
Protein hydrolysate with trypsin & $286.5 \pm 48.7^{\mathrm{a}}$ \\
Protein hydrolysate with pepsin & $189.3 \pm 57.1^{\mathrm{b}}$ \\
BHA & $297.8 \pm 29.6^{\mathrm{a}}$ \\
\hline
\end{tabular}

Values are mean of three replicate determinations $(n=3) \pm$ standard deviation. Mean values followed by different superscripts in a column $\left({ }^{a, b}\right)$ are significantly different $(p<0.05$; ANOVA, followed by Tukey's multiple comparison test).

\subsection{Purification of Antioxidant Peptides from S. ricini Pupae}

\subsubsection{Ultrafiltration}

The resulting protein hydrolysates are the acquisition of a crude peptide consisting of products of side reaction and a mixture of peptide. Ultrafiltration membranes are used for purification of biological compounds [24]. Protein hydrolysates of S. ricini pupae were fractionated by ultrafiltration using three molecular weight cut-off (MWCO) membranes $(3,10,30 \mathrm{kDa})$, and four fractions, namely, E1 (MW $>30 \mathrm{kDa}), \mathrm{E} 2(10 \mathrm{kDa}<\mathrm{MW}<30 \mathrm{kDa})$, E3 $(3 \mathrm{kDa}<\mathrm{MW}<10 \mathrm{kDa})$ and $\mathrm{E} 4(\mathrm{MW}<3 \mathrm{kDa})$ were collected. Antioxidant activities of protein hydrolysate with trypsin, comparable with BHA and BHT (positive control), are shown in Figure 1A,B. The results showed that protein hydrolysate contributes effectively to scavenging free radicals, and exhibited significant antioxidant activity compared to BHA and BHT. Protein hydrolysated with pepsin also showed significant antioxidant properties compared to positive control (Figure 1C,D). However, hydrolysate with trypsin fraction E4-T exhibited the highest DPPH radical scavenging activity $(85.7 \pm 1.8 \%)$, and iron chelating activity $(94.4 \pm 1.3 \%)$. Herein, fraction E4-T was subjected to RP-HPLC for further purification. 

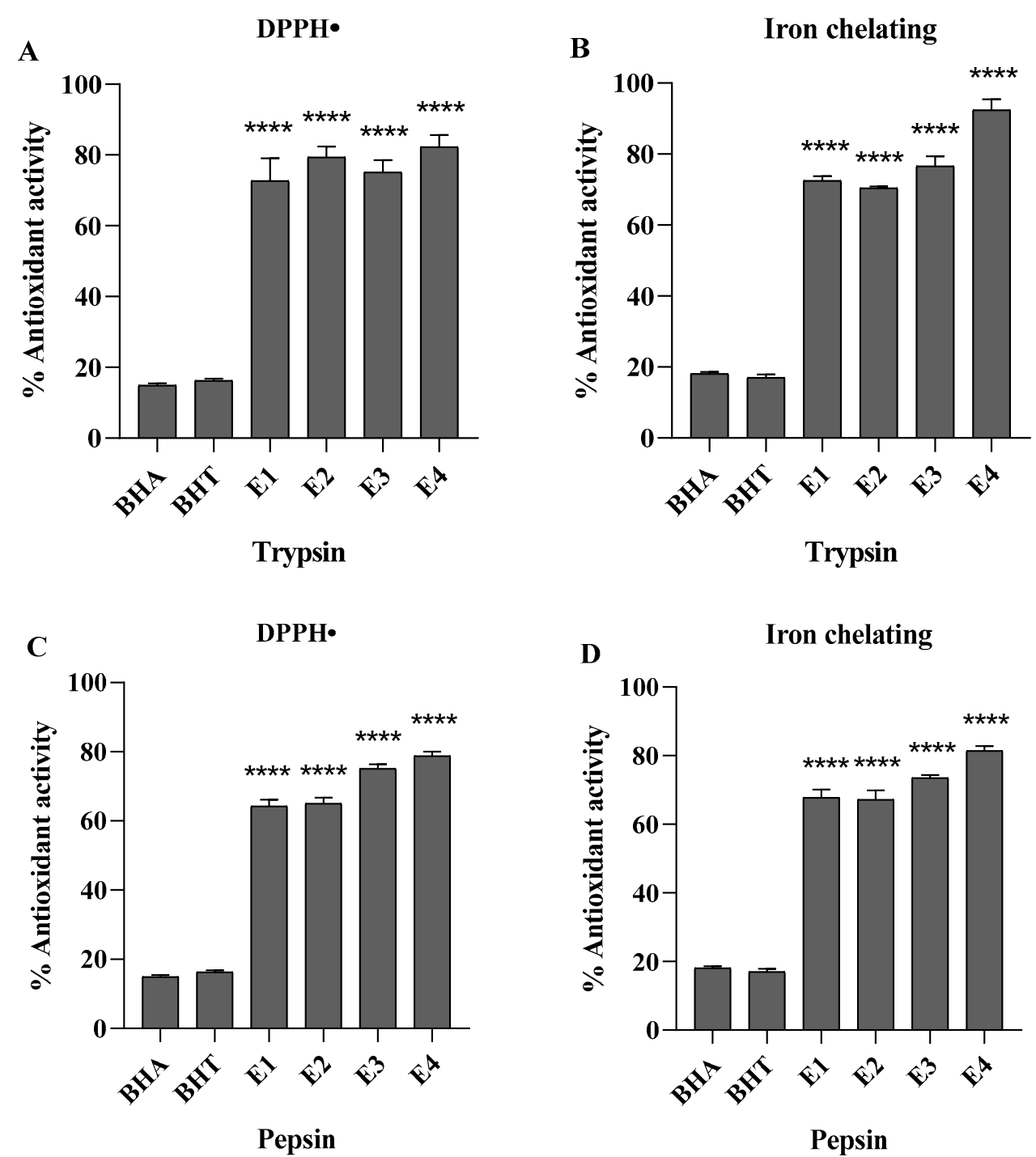

Figure 1. DPPH radical scavenging and iron-chelating activities of fractions from ultrafiltration. (A) DPPH radical scavenging activity of fractions from protein hydrolyzed with trypsin. (B) Iron-chelating activity of fractions from protein hydrolyzed with trypsin. (C) DPPH radical scavenging activity of fractions from protein hydrolyzed with pepsin. (D) Ironchelating activity of fractions from protein hydrolyzed with pepsin. All samples were tested at concentration of $1.0 \mathrm{mg} / \mathrm{mL}$. Data are presented as mean \pm standard deviation (SD) $\left(n=3,^{* * * *} p<0.0001\right.$, unpaired Student $t$-test).

3.2.2. Isolation of Peptide by Reversed-Phase High Performance Liquid Chromatography (RT-HPLC)

RP-HPLC is the dominant method for the purification of peptides and small protein [25-30]. The hydrolysate from trypsin fraction E4-T (MW $<3 \mathrm{kDa}$ ), which showed the highest antioxidant activity, were chromatographically fractionated by RP-HPLC on a Thermo C18 column. Hydrophobic peptides from column eluted using an acetonitrile gradient. E4-T was separated into 6 peaks, namely, F1 $(\mathrm{RT}=8.5 \mathrm{~min}), \mathrm{F} 2(\mathrm{RT}=11.1 \mathrm{~min})$, F3 $(\mathrm{RT}=15.6 \mathrm{~min}), \mathrm{F} 4(\mathrm{RT}=16.3 \mathrm{~min}), \mathrm{F} 5(\mathrm{RT}=17.3 \mathrm{~min})$, and F6 $(\mathrm{RT}=18.2 \mathrm{~min})$, as shown in Figure 2A. Antioxidant activities on DPPH of the separated fractions were measured (Figure 2B) and the fraction F6 exhibited the highest DPPH scavenging activity (74.7\%). Therefore, F6 was subjected to LC-MS/MS for peptide sequencing. 

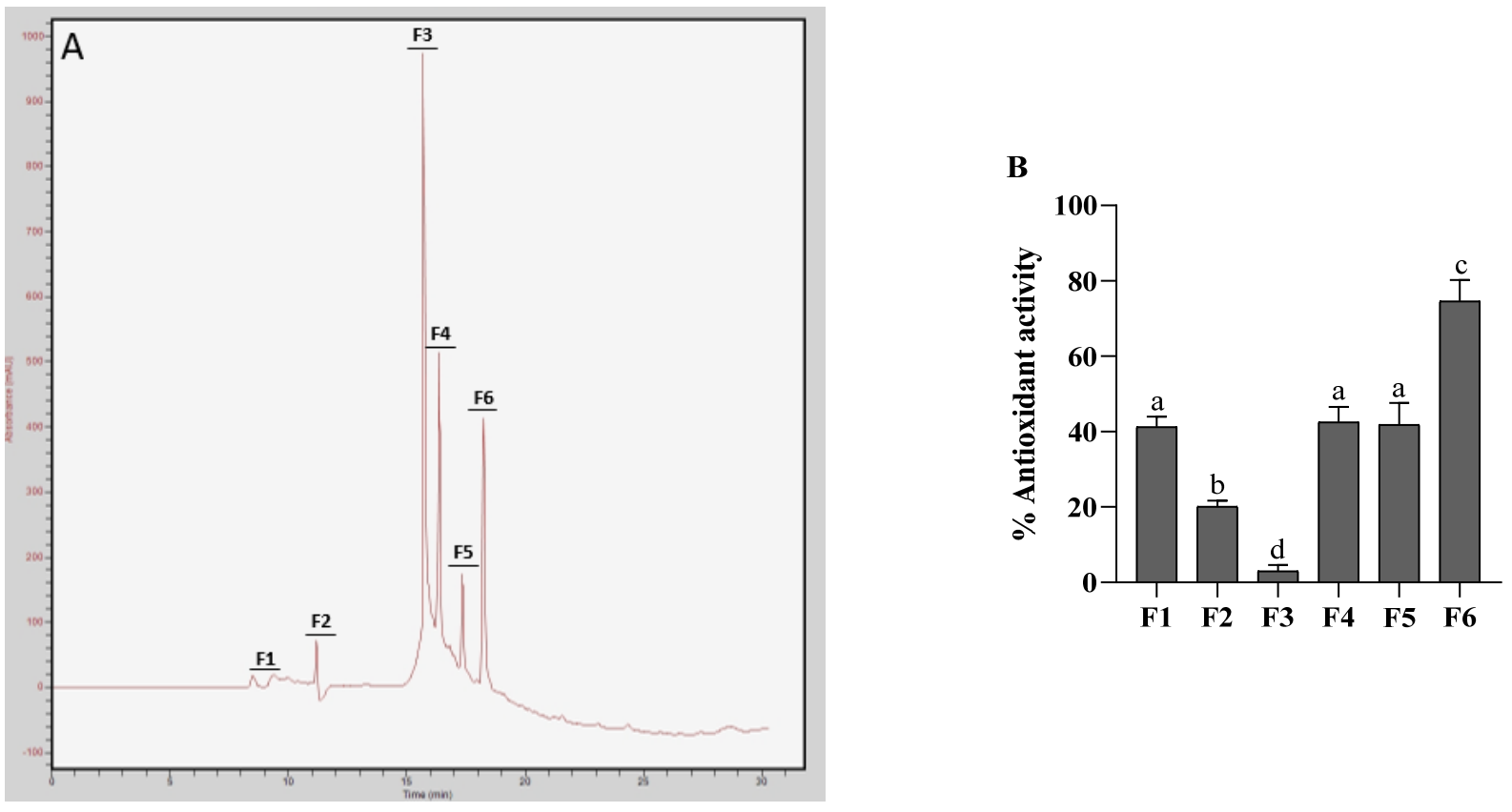

Figure 2. Purification of hydrolysate from trypsin fraction E4-T (MW < 3 kDa) by RP-HPLC on a Thermo C18 column (A), and chemical antioxidant activities of corresponding subfractions (B). Values were expressed as mean \pm SD from triplicate experiments. Bars with different letters in the same group indicated statistical differences $(p<0.05$, Duncan's test).

3.2.3. Identification of Antioxidant Peptide by Liquid Chromatography with Tandem Mass Spectrometry (LC-MS/MS)

LC-MS/MS is an effective technique because it has been widely applied for analyzing various compounds from biological samples [31-34]. In this study, the fraction F6 with highest DPPH scavenging capacity was subjected to LC-MS/MS and the results were analyzed by a combination of Mascot searching and MassLynx V4.1 software. Three major novel peptides were separated and identified, and their amino acid sequences were found to be Met-Ley-Ile-Ile-Ile-Met-Arg (MW = $904 \mathrm{Da}$ ), Leu-Asn-Lys-Asp-Leu-Met-Arg (MW = $905 \mathrm{Da}$ ), and Glu-Asn-Ile-Ile-Leu-Phe-Arg (MW = $903 \mathrm{Da})$. MS/MS spectra of each identified peptide are shown in Figure 3.

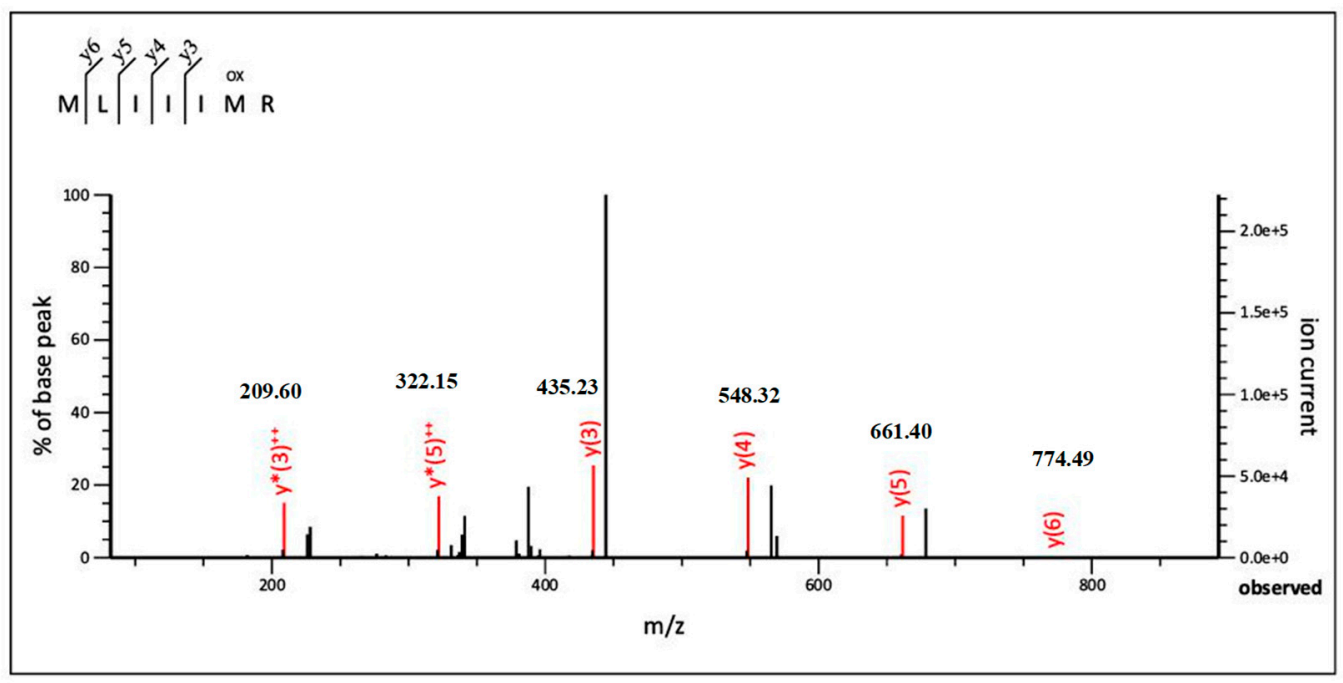

(A)

Figure 3. Cont. 


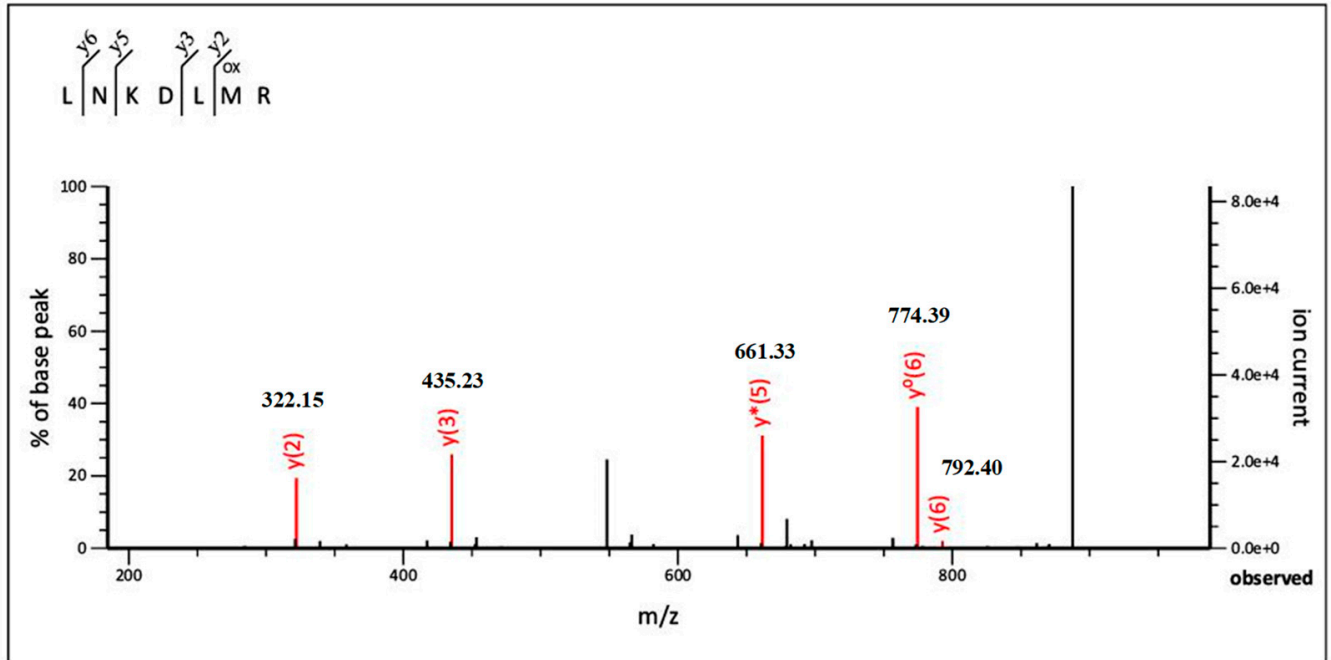

(B)

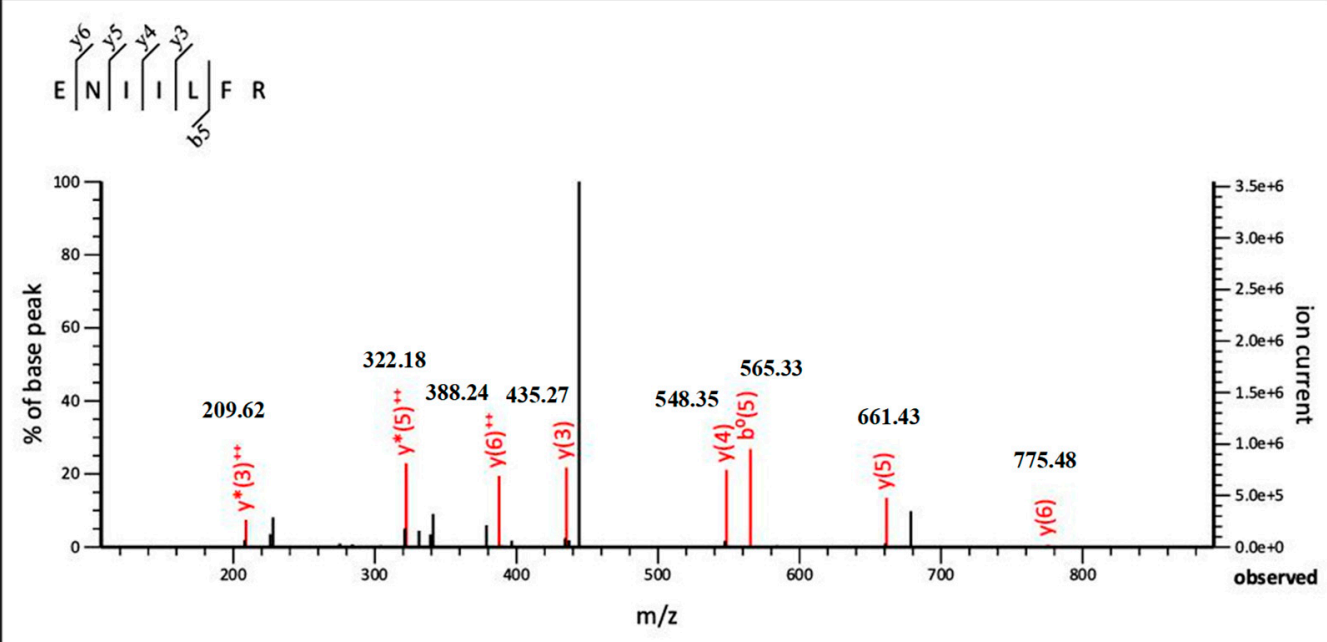

(C)

Figure 3. The second mass spectrogram of the identified peptides. (A) Mass spectrum analysis of the antioxidant peptide Met-Ley-Ile-Ile-Ile-Met-Arg. (B) Mass spectrum analysis of the antioxidant peptide Leu-Asn-Lys-Asp-Leu-Met-Arg. (C) Mass spectrum analysis of the antioxidant peptide Glu-Asn-Ile-Ile-Leu-Phe-Arg.

\section{Discussion}

Natural antioxidant peptides have been widely studied including soybean [35], mushroom (Ganoderma lucidum) [36], oyster (Saccostrea cucullata) [37], scalloped hammerhead (Sphyrna lewini) cartilage [38], and Bacillus strain CBS73 [39]. The bioactive peptides, derived from proteins of silkworm pupae (Bombyx mori), have been applied in a number of medical applications, such as immunomodulatory, antimicrobial, anticancer, and antioxidant activity [40-44], but proteins derived from S. ricini have not attracted much attention.

The bioactive peptide can be generated by hydrolysate capability, which depends on processing conditions, type of enzymes, and molecular weight of the isolated peptides $[45,46]$. The most common enzymes used for the synthesis of protein hydrolysate are alcalase, neutrase, chymotrypsin, pepsin, and trypsin [47-50]. In this study, we used trypsin and pepsin to generate protein hydrolysates. Trypsin is a family of serine endopeptidases, with preferential cleavage at carboxyl group of Arg-I-Xaa, and Lys-I-Xaa, produced in the pancreas of many vertebrates [25]. Our study found that the hydrolyzed protein by trypsin with a molecular weight lower than $3 \mathrm{kDa}$ exhibited the highest antioxidant activity. This 
is in agreement with various reports which indicated that the length of peptide affects bioavailability. Short chains show the better bioactivity than long chains [45-50].

Reversed-phase high performance liquid chromatography (HPLC) has become the method of choice for the purification of peptides and small proteins from natural sources [51]. Purification of protein hydrolysate from trypsin fraction E4-T by RT-HPLC was divided into six peaks. Fraction 6 (F6) with the highest antioxidant activity is the last fraction, standing for highly hydrophobic property. This fraction was subjected to LC-MS/MS. Three major novel peptides were separated and identified, and their amino acid sequences were found to be Met-Ley-Ile-Ile-Ile-Met-Arg (MW = 904 Da), Leu-Asn-Lys-Asp-Leu-Met-Arg (MW = 905 Da), and Glu-Asn-Ile-Ile-Leu-Phe-Arg (MW = $903 \mathrm{Da}$ ). The results of this study are consistent with the findings of the previous research that low molecular weight peptides exert a significant effect on the antioxidant activities of peptides. Among them, the composition and the sequence of amino acids have the impact on the antioxidant activity [45-50].

Previous studies have found that hydrophobic amino acids have been critical to the antioxidant activities of peptides, such as Gly-Phe-Thr-Gly-Pro-Pro-Gly-Phe-Asn-Gly $(\mathrm{MW}=950 \mathrm{Da})$ from scalloped hammerhead (Sphyrna lewini) cartilage [38], Leu-Ala-AsnAla-Lys (MW $=515 \mathrm{Da}$ ) from oyster (Saccostrea cucullata) [37], and Phe-Lys-Gly-Pro-AlaCys-Ala (MW = $692 \mathrm{Da}$ ) from Bombyx Mori [52]. A high proportion of hydrophobic amino acids has been reported in peptides with high antioxidant activity, compared to other hydrophilic amino acids [53]. As indicated, the antioxidant properties of the peptides were closely associated with their molecular weight, amino acid composition and sequence, and molecular structure [54]. Here, the identified peptides fell within a molecular weight range of 903-905 Da, consistent with previous results showing that antioxidant peptides typically contained 2-10 amino acid residues [34-39]. Moreover, it was evidenced that hydrophobic and antioxidant amino acids, such as Ile (I), Leu (L), Met (M), Phe (F), Tyr (Y), and Val (V) significantly contributed to the radical scavenging activities of peptides by enhancing their interactions with lipids or acting as potent proton/hydrogen donors [55-58].

\section{Conclusions}

In conclusion, this study suggests that antioxidative peptides obtained from S. ricini pupa protein, extracted by hydrolysate methods with trypsin, has significantly different antioxidant activity compared to synthetic antioxidants BHT and BHA. Protein hydrolysate from S. ricini pupa could be another important peptide that plays a key role in antioxidant activity. The benefits of antioxidants and their application can be instructive for the food industry to reduce the side effects resulting from the use of synthetic antioxidants.

Author Contributions: N.W.: Formal analysis, Investigation and Writing-Original draft; S.C.: Project administration, Supervision and Writing-Review and editing. All authors have read and agreed to the published version of the manuscript.

Funding: This research was funded by Faculty of Science, Kasetsart University.

Institutional Review Board Statement: Not applicable.

Informed Consent Statement: Not applicable.

Data Availability Statement: Not applicable.

Acknowledgments: This research was supported by International SciKU Branding (ISB), Faculty of Science, Kasetsart University. The LC-MS/MS analysis was supported by Sittiruk Roytrakul (National Center for Genetic Engineering and Biotechnology (BIOTEC), Thailand).

Conflicts of Interest: The authors declare that there is no conflict of interest.

Sample Availability: Samples of the S. ricini pupae are available from the authors. 


\section{References}

1. Chatterjee, S. Oxidative Stress, Inflammation, and Disease, in Oxidative Stress and Biomaterials; Elsevier: Amsterdam, The Netherlands, 2016; pp. 35-58.

2. Rowe, L.A.; Degtyareva, N.; Doetsch, P.W. DNA damage-induced reactive oxygen species (ROS) stress response in Saccharomyces cerevisiae. Free Radic. Biol. Med. 2008, 45, 1167-1177. [CrossRef]

3. Schieber, M.; Chandel, N.S. Chandel, ROS function in redox signaling and oxidative stress. Curr. Biol. 2014, 24 , R453-R462. [CrossRef]

4. Decker, E.A.; Elias, R.J.; McClements, D.J. McClements, Oxidation in Foods and Beverages and Antioxidant Applications: Understanding Mechanisms of Oxidation and Antioxidant Activity; Elsevier: Amsterdam, The Netherlands, 2010.

5. Hellwig, M. The Chemistry of Protein Oxidation in Food. Angew. Chem. Int. Ed. 2019, 58, 16742-16763. [CrossRef]

6. Conning, D.; Phillips, J. Comparative metabolism of BHA, BHT and other phenolic antioxidants and its toxicological relevance. Food Chem. Toxicol. 1986, 24, 1145-1148. [CrossRef]

7. Kahl, R.; Kappus, H. Toxicology of the synthetic antioxidants BHA and BHT in comparison with the natural antioxidant vitamin E. z Lebensm Unters Forsch 1993, 196, 329-338. [CrossRef] [PubMed]

8. Fisherman, E.W. Chemical intolerance to butylated-hydroxyanisole (BHA) and butylated-hydroxytoluene (BHT) and vascular response as an indicator and monitor of drug intolerance. Ann. Allergy 1973, 31, 126. [PubMed]

9. Gharavi, N.; El-Kadi, A.O.S. Tert-butylhydroquinone is a novel aryl hydrocarbon receptor ligand. Drug Metab. Dispos. 2004, 33, 365-372. [CrossRef] [PubMed]

10. Deori, M.; Devi, D.; Devi, R. Nutrient composition and antioxidant activities of muga and eri silkworm pupae. Int. J. Sci. Nat. 2014, 5, 636-664.

11. Longvah, T.; Mangthya, K.; Ramulu, P. Nutrient composition and protein quality evaluation of eri silkworm (Samia ricinii) prepupae and pupae. Food Chem. 2011, 128, 400-403. [CrossRef]

12. Lokeshwari, R.; Shantibala, T.; Singh, K.M.; Hazarika, B. The nutritional goldmine waste: The spent pupae of mulberry, eri and oak tasar silkworms for combating malnutrition. Int. J. Environ. Ecol. Fam. Urban Stud. 2019, 9. [CrossRef]

13. Chukiatsiri, S.; Siriwong, S.; Thumanu, K. Pupae protein extracts exert anticancer effects by downregulating the expression of IL-6, IL-1 $\beta$ and TNF- $\alpha$ through biomolecular changes in human breast cancer cells. Biomed. Pharmacother. 2020, $128,110278$. [CrossRef] [PubMed]

14. Xing, L.-J.; Hu, Y.-Y.; Hu, H.-Y.; Ge, Q.-F.; Zhou, G.-H.; Zhang, W.-G. Purification and identification of antioxidative peptides from dry-cured Xuanwei ham. Food Chem. 2016, 194, 951-958. [CrossRef] [PubMed]

15. Blois, M.S. Antioxidant Determinations by the Use of a Stable Free Radical. Nat. Cell Biol. 1958, 181, 1199-1200. [CrossRef]

16. Chaudhary, S.; Chandrashekar, K.S.; Pai, K.S.R.; Setty, M.M.; Devkar, R.A.; Reddy, N.D.; Shoja, M.H. Evaluation of antioxidant and anticancer activity of extract and fractions of Nardostachys jatamansi DC in breast carcinoma. BMC Complement. Altern. Med. 2015, 15, 50. [CrossRef]

17. Park, S.Y.; Lee, J.-S.; Baek, H.-H.; Lee, H.G. Purification and characterization of antioxidant peptides from soy protein hydrolysate. J. Food Biochem. 2010, 34, 120-132. [CrossRef]

18. Chalamaiah, M.; Jyothirmayi, T.; Diwan, P.V.; Kumar, B.D. Antioxidant activity and functional properties of enzymatic protein hydrolysates from common carp (Cyprinus carpio) roe (egg). J. Food Sci. Technol. 2015, 52, 5817-5825. [CrossRef] [PubMed]

19. Kedare, S.B.; Singh, R.P. Genesis and development of DPPH method of antioxidant assay. J. Food Sci. Technol. 2011, 48, 412-422. [CrossRef]

20. Alam, N.; Bristi, N.J. Rafiquzzaman Review on in vivo and in vitro methods evaluation of antioxidant activity. Saudi Pharm. J. 2013, 21, 143-152. [CrossRef]

21. Shavandi, A.; Hu, Z.; Teh, S.; Zhao, J.; Carne, A.; Bekhit, A.; Bekhit, A.E.-D.A. Antioxidant and functional properties of protein hydrolysates obtained from squid pen chitosan extraction effluent. Food Chem. 2017, 227, 194-201. [CrossRef] [PubMed]

22. Adjimani, J.P.; Asare, P. Antioxidant and free radical scavenging activity of iron chelators. Toxicol. Rep. 2015, 2, 721-728. [CrossRef] [PubMed]

23. Heli, H.; Mirtorabi, S.; Karimian, K. Advances in iron chelation: An update. Expert Opin. Ther. Patents 2011, 21, 819-856. [CrossRef]

24. Conidi, C.; Cassano, A.; Caiazzo, F.; Drioli, E. Separation and purification of phenolic compounds from pomegranate juice by ultrafiltration and nanofiltration membranes. J. Food Eng. 2017, 195, 1-13. [CrossRef]

25. Gholam Hossein Gudarzi, B.; Sadri, R.; Asghari, A.; Karami, S. Purification of Trypsin from Bovine Pancreas in Laboratory; Razi Vaccine and Serum Research Institute: Karaj, Iran, 2008.

26. Chi, C.-F.; Cao, Z.-H.; Wang, B.; Hu, F.-Y.; Li, Z.-R.; Zhang, B. Antioxidant and Functional Properties of Collagen Hydrolysates from Spanish Mackerel Skin as Influenced by Average Molecular Weight. Molecules 2014, 19, 11211-11230. [CrossRef]

27. Chi, C.-F.; Wang, B.; Deng, Y.-Y.; Wang, Y.-M.; Deng, S.-G.; Ma, J.-Y. Isolation and characterization of three antioxidant pentapeptides from protein hydrolysate of monkfish (Lophius litulon) muscle. Food Res. Int. 2014, 55, 222-228. [CrossRef]

28. Grimble, G.; Rees, R.; Keohane, P.; Cartwright, T.; Desreumaux, M.; Silk, D. Effect of peptide chain length on absorption of egg protein hydrolysates in the normal human jejunum. Gastroenterology 1987, 92, 136-142. [CrossRef] 
29. Ko, J.-Y.; Lee, J.-H.; Samarakoon, K.; Kim, J.-S.; Jeon, Y.-J. Purification and determination of two novel antioxidant peptides from flounder fish (Paralichthys olivaceus) using digestive proteases. Food Chem. Toxicol. 2013, 52, 113-120. [CrossRef] [PubMed]

30. Wang, B.; Gong, Y.-D.; Li, Z.-R.; Yu, D.; Chi, C.-F.; Ma, J.-Y. Isolation and characterisation of five novel antioxidant peptides from ethanol-soluble proteins hydrolysate of spotless smoothhound (Mustelus griseus) muscle. J. Funct. Foods 2014, 6, 176-185. [CrossRef]

31. Chalamaiah, M.; Hemalatha, R.; Jyothirmayi, T.; Diwan, P.V.; Bhaskarachary, K.; Vajreswari, A.; Kumar, R.R.; Kumar, B.D. Chemical composition and immunomodulatory effects of enzymatic protein hydrolysates from common carp (Cyprinus carpio) egg. Nutrition 2015, 31, 388-398. [CrossRef] [PubMed]

32. Tanzadehpanah, H.; Asoodeh, A.; Chamani, J. An antioxidant peptide derived from Ostrich (Struthio camelus) egg white protein hydrolysates. Food Res. Int. 2012, 49, 105-111. [CrossRef]

33. He, R.; Alashi, A.; Malomo, S.A.; Girgih, A.T.; Chao, D.; Ju, X.; Aluko, R.E. Antihypertensive and free radical scavenging properties of enzymatic rapeseed protein hydrolysates. Food Chem. 2013, 141, 153-159. [CrossRef]

34. Pan, X.-Y.; Wang, Y.-M.; Li, L.; Chi, C.-F.; Wang, B. Four Antioxidant Peptides from Protein Hydrolysate of Red Stingray (Dasyatis akajei) Cartilages: Isolation, Identification, and In Vitro Activity Evaluation. Mar. Drugs 2019, 17, 263. [CrossRef]

35. Zhang, Q.; Tong, X.; Li, Y.; Wang, H.; Wang, Z.; Qi, B.; Sui, X.; Jiang, L. Purification and Characterization of Antioxidant Peptides from Alcalase-Hydrolyzed Soybean (Glycine max L.) Hydrolysate and Their Cytoprotective Effects in Human Intestinal Caco-2 Cells. J. Agric. Food Chem. 2019, 67, 5772-5781. [CrossRef] [PubMed]

36. Sun, J.; He, H.; Xie, B.J. Novel Antioxidant Peptides from Fermented MushroomGanoderma lucidum. J. Agric. Food Chem. 2004, 52, 6646-6652. [CrossRef]

37. Umayaparvathi, S.; Meenakshi, S.; Vimalraj, V.; Arumugam, M.; Sivagami, G.; Balasubramanian, T. Antioxidant activity and anticancer effect of bioactive peptide from enzymatic hydrolysate of oyster (Saccostrea cucullata). Biomed. Prev. Nutr. 2014, 4, 343-353. [CrossRef]

38. Li, X.-R.; Chi, C.-F.; Li, L.; Wang, B. Purification and Identification of Antioxidant Peptides from Protein Hydrolysate of Scalloped Hammerhead (Sphyrna lewini) Cartilage. Mar. Drugs 2017, 15, 61. [CrossRef]

39. Kim, M.; Khan, M.M.; Yoo, J.C. Antimicrobial and antioxidant peptide from Bacillus strain CBS73 isolated from Korean Food. J. Chosun Nat. Sci. 2017, 10, 154-161.

40. Li, Z.; Zhao, S.; Xin, X.; Zhang, B.; Thomas, A.; Charles, A.; Lee, K.S.; Jin, B.R.; Gui, Z. Purification and characterization of a novel immunomodulatory hexapeptide from alcalase hydrolysate of ultramicro-pretreated silkworm (Bombyx mori) pupa protein. J. Asia Pac. Èntomol. 2019, 22, 633-637. [CrossRef]

41. Li, Z.; Zhao, S.; Xin, X.; Zhang, B.; Thomas, A.; Charles, A.; Lee, K.S.; Jin, B.R.; Gui, Z. Purification, Identification and Functional Analysis of a Novel Immunomodulatory Peptide from Silkworm Pupa Protein. Int. J. Pept. Res. Ther. 2019, 26, 243-249. [CrossRef]

42. Heo, J.E.; Ryu, J.H.; Jeong, H.K.; Chung, W.T.; Ahn, M.Y. Antioxidant Activity of cholesterol derived from silkworm pupae. Nat. Prod. Sci. 2007, 13, 220.

43. Anootthato, S.; Therdthai, N.; Ritthiruangdej, P. Characterization of protein hydrolysate from silkworm pupae (Bombyx mori). J. Food Process. Preserv. 2019, 43, 14021. [CrossRef]

44. Chatsuwan, N.; Puechkamut, Y.; Pinsirodom, P. Characterization, Functionality and Antioxidant Activity of Water-Soluble Proteins Extracted from Bombyx mori Linn. Curr. Appl. Sci. Technol. 2018, 18, 83-96.

45. Jung, K.-H.; Choi, Y.-C.; Chun, J.-Y.; Min, S.-G.; Hong, G.-P. Effects of Concentration and Reaction Time of Trypsin, Pepsin, and Chymotrypsin on the Hydrolysis Efficiency of Porcine Placenta. Food Sci. Anim. Resour. 2014, 34, 151-157. [CrossRef] [PubMed]

46. Wu, R.; Wu, C.; Liu, D.; Yang, X.; Huang, J.; Zhang, J.; Liao, B.; He, H. Antioxidant and anti-freezing peptides from salmon collagen hydrolysate prepared by bacterial extracellular protease. Food Chem. 2018, 248, 346-352. [CrossRef]

47. Zhu, L.; Chen, J.; Tang, X.; Xiong, Y.L. Reducing, Radical Scavenging, and Chelation Properties of in Vitro Digests of AlcalaseTreated Zein Hydrolysate. J. Agric. Food Chem. 2008, 56, 2714-2721. [CrossRef]

48. Zhang, J.; Zhang, H.; Wang, L.; Guo, X.; Wang, X.; Yao, H. Antioxidant activities of the rice endosperm protein hydrolysate: Identification of the active peptide. Eur. Food Res. Technol. 2009, 229, 709-719. [CrossRef]

49. Chen, C.; Chi, Y.-J.; Zhao, M.-Y.; Lv, L. Purification and identification of antioxidant peptides from egg white protein hydrolysate. Amino Acids 2011, 43, 457-466. [CrossRef]

50. Wu, H.-C.; Chen, H.-M.; Shiau, C.-Y. Free amino acids and peptides as related to antioxidant properties in protein hydrolysates of mackerel (Scomber austriasicus). Food Res. Int. 2003, 36, 949-957. [CrossRef]

51. Shaw, C. Peptide Purification by Reverse-Phase HPLC. Basic Protein Pept. Protoc. 1994, 32, 275-288. [CrossRef]

52. Zhang, Y.; Wang, J.; Zhu, Z.; Li, X.; Sun, S.; Wang, W.; Sadiq, F.A. Identification and characterization of two novel antioxidant peptides from silkworm pupae protein hydrolysates. Eur. Food Res. Technol. 2021, 247, 343-352. [CrossRef]

53. Esteve, C.; Marina, M.; García, M. Novel strategy for the revalorization of olive (Olea europaea) residues based on the extraction of bioactive peptides. Food Chem. 2015, 167, 272-280. [CrossRef] [PubMed]

54. Zarei, M.; Ebrahimpour, A.; Abdul-Hamid, A.; Anwar, F.; Abu Bakar, F.; Philip, R.; Saari, N. Identification and characterization of papain-generated antioxidant peptides from palm kernel cake proteins. Food Res. Int. 2014, 62, 726-734. [CrossRef]

55. Daliri, E.B.-M.; Oh, D.H.; Lee, B.H. Bioactive Peptides. Foods 2017, 6, 32. [CrossRef] [PubMed] 
56. Tagliazucchi, D.; Martini, S.; Solieri, L. Bioprospecting for Bioactive Peptide Production by Lactic Acid Bacteria Isolated from Fermented Dairy Food. Fermentation 2019, 5, 96. [CrossRef]

57. Nielsen, S.D.; Beverly, R.L.; Qu, Y.; Dallas, D.C. Milk bioactive peptide database: A comprehensive database of milk proteinderived bioactive peptides and novel visualization. Food Chem. 2017, 232, 673-682. [CrossRef] [PubMed]

58. Bhandari, D.; Rafiq, S.; Gat, Y.; Gat, P.; Waghmare, R.; Kumar, V. A Review on Bioactive Peptides: Physiological Functions, Bioavailability and Safety. Int. J. Pept. Res. Ther. 2020, 26, 139-150. [CrossRef] 